\title{
Phylogenetic relationships, based on SSU rDNA sequences, among the didelphic genera of the family Trichodoridae from Portugal
}

\author{
Isabel M. DuARTE 1,*, Maria Teresa M. DE Almeida 2, Derek J.F. Brown 3, Isabel MARQues 4, Roy \\ NEILSON 5 and Wilfrida DECRAEMER 6 \\ ${ }_{1}$ Departamento de Biologia e Ecologia, Escola Superior Agrária de Coimbra, Bencanta, 3040-316 Coimbra, Portugal 2 \\ Departamento de Biologia, Universidade do Minho, Campus de Gualtar, 4710-057 Braga, Portugal 3 Central Laboratory of \\ General Ecology, Gagarin Street 2, 1113 Sofia, Bulgaria 4 Instituto Gulbenkian de Ciência, Rua da Quinta Grande, 6, 2781- \\ 901 Oeiras, Portugal 5 Scottish Crop Research Institute, Invergowrie, Dundee DD2 5DA, UK 6 Royal Belgian Institute of \\ Natural Sciences, Brussels, Belgium
}

Received: 31 January 2009; revised: 15 May 2009 Accepted for publication: 18 May 2009

\begin{abstract}
Summary - A survey of virus vector trichodorid nematodes was carried out in the central and northern regions of Portugal. Morphobiometric identification showed the presence of trichodorid species previously reported from Portugal, except for Paratrichodorus porosus, which is reported for the first time in Continental Europe. Small subunit ribosomal DNA (SSU rDNA) sequences of ten different species occurring in Portugal were obtained and a phylogenetic analysis based on their alignment was performed to infer relationships among the different Portuguese trichodorid species and three non-indigenous populations (Nanidorus minor, $P$. allius and $P$. teres). The re- sulting phylogenetic tree is in agreement with the currently accepted classification for Trichodoridae, except for Nanidorus, which clusters together with Trichodorus species, while the genera Paratrichodorus and Trichodorus appear as two distinct groups. A better understanding of the generic groupings in the family Trichodoridae was found. Based on the new molecular analyses we herein accept Nanidorus as a valid genus.

Keywords - 18S rDNA, molecular, Nanidorus, Paratrichodorus, Paratrichodorus porosus, phylogeny, tobacco rattle virus (TRV), Trichodorus, Tylolaimophorus minor.
\end{abstract}

